\title{
A Letter from the Editor-in-Chief: In this Issue of BECT
}

\author{
Erin Bennett ${ }^{1}$
}

Received: 21 September 2016 / Accepted: 27 September 2016 / Published online: 8 October 2016

(C) Springer Science+Business Media New York 2016

With only a couple of months remaining in 2016, I am very pleased with all of the contributions made to BECT to help celebrate its 50th Anniversary, and would like to once again thank all of the contributors and editors. In this issue, Dr. Gary Heinz provides an interesting retrospective on his 1974 publication, "Effects of Low Dietary Levels of Methyl Mercury on Mallard Reproduction" (Heinz 2016). Also in this issue, Schmitt and McKee (2016) provide a detailed look at the current status of the Big River, Missouri, Superfund site with respect to human consumption advisories for lead in fish relative to ongoing remediation efforts. One of the original monitoring datasets for the Big River, which focused public attention on the issue of lead mining tailings, was published in BECT (Czarnezki 1985). I have provided a summary of the Schmitt and McKee paper below. Finally, please take the time to review the Table of Contents for this issue so that you can further explore the range of interesting topics that BECT offers its readers.

Briefly, the Big River drains the Old Lead Belt Sub-district of the Southeast Missouri Lead Mining District, which hosts the world's largest known deposits of lead-zinc ore and where mining has occurred since the early 1800s (Wixson 1977). The last mine in the Old Lead Belt ceased operation in 1972. In 1977, an unmaintained tailings dam in the Old Lead Belt collapsed, which resulted in the release of some $38,000 \mathrm{~m}^{3}$ of contaminated material to the Big River (Novak and Hasselwander 1980). Continuing erosion from this site and other sites resulted in contamination of the entire river downstream of the Old Lead Belt, which was

Erin Bennett

ebennett@uwindsor.ca

1 University of Windsor, Windsor, ON, Canada added to the National Priorities List by the U.S. Environmental Protection Agency in 1992 (USEPA 2016). The Missouri Department of Conservation began collecting fish for lead analysis following the 1977 dam failure. Based on the results of these analyses, the public has been advised since 1980 not to eat certain species of fish from the Big River downstream of the Old Lead Belt. In 1985, results of the first few years of fillet monitoring results were published in the Bulletin of Environmental Contamination and Toxicology (Czarnezski 1985).

Much of the environmental remediation undertaken to date in the Old Lead Belt has focused on curtailing the input of tailings to the Big River and its tributaries, and additional remediation is being considered (USEPA 2016). One objective of remediation is to reduce lead concentrations in fish and rescind the consumption advisory, which cannot be accomplished without clear evidence that the fish are safe to eat. Lead occurs in animals as a trace contaminant of calcium; it can replace calcium and accumulate in calcium rich tissues such as bone and scale. Lead concentrations in muscle are low; however, measured concentrations of lead in fish fillets can vary widely depending on the amount of calcium-rich tissues (i.e., scale and bone) in the samples and external contamination by mucus, both of which can reflect differing preparation methods (Schmitt and Finger 1987; Schmitt et al. 2007). Consequently, ascertaining the extent to which concentrations in fish from the Big River have declined (or not) in response to remediation was challenging question for Schmitt and Mckee to address.

In the current article by Schmitt and McKee (2016), a method for normalizing fillet lead concentrations to fillet calcium as a means of controlling for extraneous variation related to sampling technique was developed. Comparisons of concentrations in samples collected during 2005-12 with those from previous surveys (including Czarnezki 
1985) were analyzed. The authors proposed that 2005-12 concentrations prepared and analyzed according to the procedures in this paper be considered as a benchmark for evaluating future environmental remediation in the Big River watershed.

\section{References}

Czarnezki J (1985) Accumulation of lead in fish from Missouri streams impacted by lead mining. Bull Environ Contam Toxicol $34: 736-745$

Heinz G (2016) A downstream voyage of mercury. Bull Environ Contam Toxicol. doi:10.1007/s00128-016-1909-1

Novak JT, Hasselwander GB (1980) Control of mine tailings discharges to Big River. Missouri Department of Natural Resources Report, Jefferson City, pp 75
Schmitt CJ, Finger SE (1987) The effects of sample preparation on the measured concentrations of eight elements in the edible tissues of fish contaminated by lead mining. Arch Environ Contam Toxicol 16:185-207

Schmitt CJ, McKee MJ (2016) Declining concentrations of lead and calcium-normalized lead in fish fillets from the Big River, a mining-contaminated stream in Southeastern Missouri, USA. Bull Environ Contam Toxicol. doi:10.1007/s00128-016-1850-3

Schmitt CJ, Brumbaugh WG, May TW (2007) Accumulation of metals in fish from lead-zinc mining areas of southeastern Missouri, USA. Ecotoxicol Environ Saf 67:14-30

USEPA (2016) EPA superfund program: Big River mine tailings/St. Joe Minerals Corp., Desloge, MO, https://cumulis.epa.gov/super$\mathrm{cpad} /$ cursites/csitinfo.cfm?id=0701639. Accessed 29 Mar 2016

Wixson BG (ed) (1977) The Missouri lead study, vol I. National Science Foundation, Washington, DC, pp 543 